Biochimie

November 2015, Volume 118, Pages 286-293

http://dx.doi.org/10.1016/i.biochi.2015.05.011

http://archimer.ifremer.fr/doc/00270/38113/

(c) 2015 Elsevier B.V. and Societe Française de Biochimie et Biologie

Moleculaire (SFBBM). All rights reserved

\title{
Restoration of the di-myo-inositol-phosphate pathway in the piezo-hyperthermophilic archaeon Thermococcus barophilus
}

\author{
Cario Anaïs ${ }^{1}$, Mizgier Alex ${ }^{1}$, Thiel Axel $^{2,3,4}$, Jebbar Mohamed ${ }^{2,3,4}$, Oger Phil M. ${ }^{1, *}$
}

${ }^{1}$ Laboratoire de Géologie de Lyon, CNRS UMR 5276, ENS de Lyon, 46 Allée d'Italie, Lyon France

${ }^{2}$ Université Bretagne Occidentale (UBO), IUEM (Institut Universitaire Européen de la mer) - UMR 6197, Technopole Brest-Iroise, Place Nicolas Copernic, F-29280 Plouzané, France

${ }^{3}$ CNRS, IUEM (Institut Universitaire Européen de la mer) - UMR 6197, Technopole Brest-Iroise, Place Nicolas Copernic, F-29280 Plouzané, France

${ }^{4}$ Ifremer, UMR 6197, Technopole Brest-Iroise, Place Nicolas Copernic, F-29280 Plouzané, France

* Corresponding author : Phil M. Oger, email address : poger@ens-lyon.fr

\begin{abstract}
:
Most Thermococcales accumulate di-myo-inositol-phosphate (DIP) as an organic solute as a response to heat stress. We have studied the accumulation of this osmolyte in the high-hydrostatic pressure adapted hyperthermophile Thermococcus barophilus. We found no accumulation of DIP under any of the stress conditions tested, although this archaeon harbors the 3 DIP synthesis genes. Lack of synthesis is due to the lack of expression of TERMP_01135 coding for the second step of DIP synthesis. In contrast to other species, the $T$. barophilus synthesis operon is interrupted by a four gene locus, in reverse orientation. Restoring an operon like structure at the DIP locus restored DIP synthesis, but did not have an impact on growth characteristics, suggesting that other mechanisms have evolved in this organism to cope with heat stress.
\end{abstract}

\section{Graphical abstract}

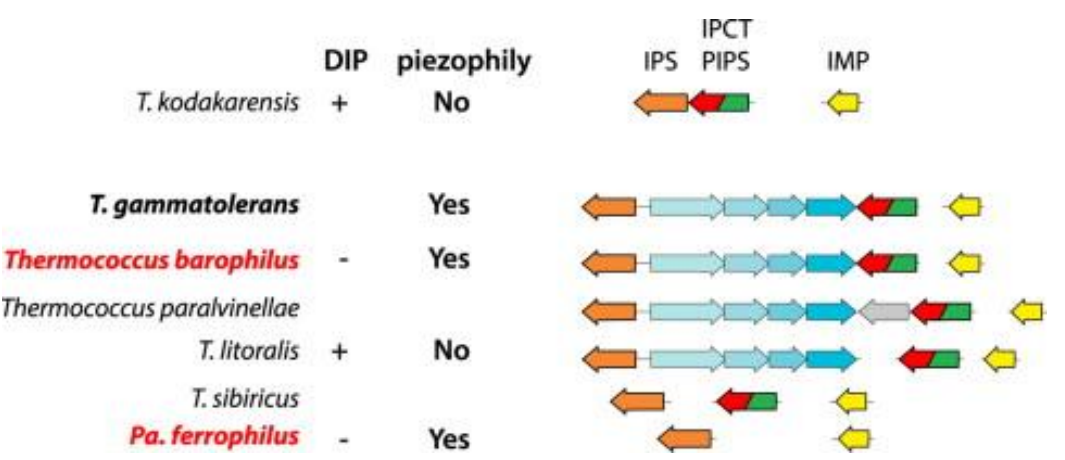




\section{Highlights}

- T. barophilus lacks the accumulation of the thermal osmolyte di-myo-1,1'-inositol phospahte (DIP). Lack of DIP synthesis is due to the lack of expression of the IMPCT/PDIPS gene. Mannosylglycerate compensates for the lack of DIP synthesis during thermal stress. Restoring the ability to synthesize DIP did not impact the thermal stress response.

Keywords: High hydrostatic pressure, Heat stress, di-myo-inositol-phosphate, Thermococcus barophilus 


\section{INTRODUCTION}

Hydrothermal vents are characterized by large temperature fluctuations from fluid temperatures as high as $400^{\circ} \mathrm{C}$ (Cayman Trough, Western Caribbean Sea) at the heart of the vent, to

$2^{\circ} \mathrm{C}$, the average temperature of the surrounding deep ocean waters [1]. Due to this extremely steep gradient and the fluctuating environment, it is expected that microorganisms from hydrothermal vents express a strong thermal stress response [8-10]. In a simplistic view, the effects of heat stress on cells and cell structures can be explained by a single factor, e.g. the reduced activity of water, inside or in the vicinity of the cells. Under reduced water activity, improper folding of protein occur and reduce or abolish protein activity, which has numerous cellular consequences [11]. A common strategy among microorganisms to cope with thermal stress involves the accumulation of lowmolecular-mass organic compounds. These are named compatible solutes, because they do not interfere with cellular metabolism [2-4]. Compatible solutes of hyperthermophiles are similar to those used in mesophiles, i.e. sugars, amino acids, polyols. Hyperthermophiles also accumulate specific solutes, little or never encountered in mesophiles, such as mannosylglycerate (MG) [6, 12], di-myo-1,1'-inositol phosphate (DIP) [13, 14], diglycerol phosphate and derivatives of these compounds $[15,16]$. While MG is accumulated mostly in response to high salinity [10, 17], DIP is usually accumulated in response to high temperatures $[5,6,18]$. Osmolytes, such as MG or DIP, help maintain proper protein folding and protein function [19] and permit normal enzyme activity,

53 i.e. prevent protein denaturation, in response to osmotic and heat stress [4, 16, 20]. MG has been 54 shown to preserve protein folding through an increase of protein rigidity [21, 22]. extremely high hydrostatic pressures (HHP), which can reach $110 \mathrm{MPa}$, e.g. 1100 times the

57 atmospheric pressure, at the bottom of the Marianna Trench [23, 24]. HHP is known to impact 
59 lowering of temperature, since it will reinforce the structure of some molecules, such as membrane

60 lipids, and an increase in temperature, since it will as well destabilize other structures, such as

61 proteins [26]. In a simplistic approach, the impact of HHP may be reduced to the Le Chatelier

62 general law of chemical equilibrium, which implies that an increase in pressure will favor the

63 smallest state in a chemical system [27]. Thus, if the volume of the native protein is smaller than the

64 volume of the unfolded protein, this protein will be stabilized by pressure, and conversely.

65 Moderate pressure often increases thermal stability of proteins [25, 28], and consequently protein

66 efficiency is often reported [28]. Several pressure-adapted, i.e. piezophilic, microorganisms have

67 been isolated from various deep-sea hydrothermal vents [29-31], which grow optimally at

68 hydrostatic pressures higher than $0.1 \mathrm{MPa}$. In piezophiles, some proteins show a better tolerance at

69 high pressure than their homologs from piezosensitive isolates [32-34]. In the SSB protein of

70 Photobacterium profundum this enhanced tolerance has been linked to an increase in Proline

71 content leading to increased rigidity of the protein structure [35], a mechanism essentially similar to

72 that observed for the stabilization of proteins to osmotic and thermal stresses by the osmolytes MG

73 and DIP [21, 22]. Knowing the antagonistic or emphasizing effects of HHP and temperature on

74 macromolecular structures in the cells, it was interesting to characterize the nature of the cell

75 response to heat stress in piezophilic hyperthermophiles.

One of the first piezophilic isolate was Thermococcus barophilus strain MP, isolated from

77 the Snake Pit hydrothermal vent system on the Mid-Atlantic Ridge, which grows optimally at

$7840 \mathrm{MPa}, 85^{\circ} \mathrm{C}$ and $3 \%$ salinity [30]. Most of the hyperthermophilic piezophiles belong to the same

79 family, the Thermococcales [26]. In Thermococcales such as T. celer [5] or P. furiosus [6], DIP is

80 accumulated in amounts above $1 \mu \mathrm{mol} / \mathrm{mg}$ of protein. DIP is synthesized from glucose-6-phosphate

81 in three steps, encoded by three genes: an Inositol-1-phosphate synthase (IPS), a bifunctional

82 CTP:Inositol-1-phosphate cytidylyltransferase/Phospho-di-inositol-1-phosphate synthase 
83 (IPCT/PIPS) and an Inositol-1-monophosphatase (IMP). In most Thermococcus, the IPCT/PIPS and

84 the IPS genes form a 2-gene operon-like structure, while the IMP gene is located in another 85 genomic location (Figure 1) [36-38]. The three genes being present in T. barophilus strain MP is consistent with this strain expressing a heat stress response similar to that of other Thermococcales.

barophilus by monitoring the accumulation of DIP as a function of temperature in the wild-type strain MP. We show that this strain does not accumulate detectable levels of DIP under any temperature conditions tested. We show that this inability originates from the lack of expression of

91 the IPCT/PIPS gene. Restoring the IPS/IPCT/PIPS operon restored DIP synthesis in T. barophilus

92 mutants, but did not affect growth characteristics.

\section{MATERIALS AND METHODS}

\subsection{Microorganisms and growth conditions}

Thermococcus barophilus strain MP was grown in Thermococcales Rich Medium (TRM) [31].

Cultivation at low pressure was performed in sealed serum vials while cultures under HHP were performed in sterile syringes as previously described [30]. Cultures were inoculated with $0.5 \%(\mathrm{v}, \mathrm{v})$ of a glycerol stock, stored anaerobically at $-80^{\circ} \mathrm{C}$ at a starting cell concentration of $5.10^{5}$ cells per milliliter. Cell growth was monitored by direct cell counts in a Thomas chamber $(0.01 \mathrm{~mm}$ depth).

101 Experiments were performed at least in triplicate.

\subsection{Construction of DIP synthesis restoration mutants}

103 Deletion mutants of the 4-gene putative sugar transporter encoded by genes TERMP_01131-

104 TERMP_01134 were obtained as described in Thiel et al. (2014) [39] using a knockout plasmid 105 containing the IPS (TERMP_01130) and IPCT/PIPS (TERMP_01135) genes, in which the TGA 


\section{Cario et al.}

\section{ACCEPTED MANUSCRIPIT}

\section{Restoration of DIP synthesis in T. barophilus}

106 codon of IPCT/PIPS was fused to base -63 upstream of the ATG of the IPS ORF. Proper deletion was confirmed by PCR amplification and sequencing using primers located on either sides of the deletion (Table 1). T. barophilus mutant derivative $\mathrm{Tb} \Delta \mathrm{PST} 1$ is available from strain collection of the University of Britany (Souchothèque de Bretagne, http://www.univ-brest.fr/souchotheque/) under the strain number UBOCC 3259.

\subsection{RNA extraction, reverse transcription and quantitative PCR}

112 Total RNAs were extracted from mid-exponential phase cultures following a single step RNA

113 extraction procedure adapted from $P$. furiosus $[40,41]$. The RNAs were treated with DNAse and

114 further purified with the RNeasy kit from Qiagen according to the manufacturer's instructions. The

115 absence of residual genomic DNA was verified by direct PCR amplification using gene targets

116 listed in table 1. Total RNA were reverse transcribed using the RevertAid ${ }^{\mathrm{TM}} \mathrm{H}$ Minus Reverse

117 Transcriptase kit (Fermentas, Lituany). The resulting cDNA was used as a template for target

118 specific PCR amplification using primer pairs for each DIP genes (Table 1). RT-qPCR assays were

119 performed on a Mx3000 QPCR system (Agilent Technologies, Santa Clara, CA, USA) using the

120 Brilliant II Ultra-Fast SYBR ${ }^{\circledR}$ Green QPCR master mix (Stratagene, La Jolla, CA, USA). The $20 \mu 1$

121 reactions contained $1 \mu \mathrm{l}$ of target $\operatorname{cDNA}\left(1 \mathrm{ng} . \mu \mathrm{l}^{-1}\right), 0.3 \mu \mathrm{l}$ of 1/500 diluted reference dye and 1

$122 \mu \mathrm{mol} .1^{-1}$ of each forward and reverse primers. Negative controls without template were included in 123 each run. A specific cloned reference was used for each target gene. Transcripts levels were 124 normalized to $16 \mathrm{~S}$ rRNA genes. Values are reported as a ratio of expression levels relative to growth 125 conditions under optimal temperature at atmospheric pressure.

2.4 Extraction of intracellular solutesT. barophilus cells (Total of $10^{10}$ ) were harvested in midexponential phase by centrifugation $\left(5000 \mathrm{~g}, 15 \mathrm{~min}, 4^{\circ} \mathrm{C}\right)$, washed once with an isotonic $\mathrm{NaCl}$

128 solution, and extracted by the method of Reed [42] with the exception that the extraction was 129 performed for $30 \mathrm{~min}$ in boiling $80 \%$ ethanol. Cells were removed by centrifugation $10 \mathrm{~min}$ at 
Cario et al.

$13012000 \mathrm{~g}$ at $4^{\circ} \mathrm{C}$. Supernatants were transferred to a clean tube and lyophilized (Alpha 1-2 LDplus,

131 Martin Christ, Germany). The dried residue was dissolved in $\mathrm{D}_{2} \mathrm{O}$ for NMR analyzes.

$132 \quad 2.5$ NMR spectroscopy

133 All spectra were acquired on a Bruker DRX 500 spectrometer at room temperature and $30^{\circ}$ pulse.

$134{ }^{13} \mathrm{C}$-NMR spectra were acquired at $125.8 \mathrm{MHz}$ using a TCI ${ }^{1} \mathrm{H} /{ }^{13} \mathrm{C} /{ }^{15} \mathrm{~N} 5 \mathrm{~mm}$ probehead. ${ }^{31} \mathrm{P}-\mathrm{NMR}$ 135 spectra were acquired at $202.5 \mathrm{MHz}$ using a $5 \mathrm{~mm} \mathrm{TBI}{ }^{1} \mathrm{H} /\{\mathrm{BB}\} /{ }^{13} \mathrm{C}$ probe. NMR studies were 136 performed at the Institut des Sciences Analytiques of the CNRS (ISA, Villeurbane, France).

\section{RESULTS AND DISCUSSION}

3.1 Characterization of the heat stress response in T. barophilus.

T. barophilus strain MP grows from ca. $65^{\circ} \mathrm{C}$ to $95^{\circ} \mathrm{C}$ at atmospheric pressure, and up to $100^{\circ} \mathrm{C}$ at $40 \mathrm{MPa}$, with an optimum at $85^{\circ} \mathrm{C}$ at both pressures [9]. To optimize thermal stress conditions, T. barophilus was grown in TRM [31] at varying temperatures ranging form $65^{\circ} \mathrm{C}$ to

$14398^{\circ} \mathrm{C}$ under optimal pressure and salinity conditions, e.g $40 \mathrm{MPa}$ and $3 \% \mathrm{NaCl}$. As expected, the 144 highest growth rate and largest cell yields were obtained for cultures at $85^{\circ} \mathrm{C}$. Growth yields below $14575^{\circ} \mathrm{C}$ and above $95^{\circ} \mathrm{C}$ were severely affected and could not yield enough cellular material for 146 further osmolyte extraction. Temperatures between $80^{\circ} \mathrm{C}$ and $90^{\circ} \mathrm{C}$ showed little impact on growth 147 parameters, inducing only a short, ca. 2h, growth lag, while a longer growth retardation (ca. 6-8h) 148 and reduced growth yield $(0.3 \log )$ was observed for growth at $95^{\circ} \mathrm{C}$. Based on these results, $80^{\circ} \mathrm{C}$ 149 was chosen as the sub-optimal temperature growth condition and $90^{\circ} \mathrm{C}$ and $95^{\circ} \mathrm{C}$ were chosen as 150 supra-optimal temperatures. Atmospheric pressure was chosen as the low pressure. The supra151 optimal pressure condition was fixed at 70MPa, which was previously shown to match growth 152 parameters for strain $\mathrm{MP}$ at $0.1 \mathrm{MPa}$ [31]. 
Organic solutes were extracted from T. barophilus cells grown under these 4 temperature,

154 and 3 pressure conditions yielding 12 different pressure $\mathrm{x}$ temperature conditions. DIP extracted from $P$. furiosus grown under optimal temperature conditions $\left(100{ }^{\circ} \mathrm{C}, 0.1 \mathrm{MPa}\right)$ was used as a positive control for extraction and analysis. The ethanol extracts were examined by natural abundance ${ }^{1} \mathrm{H}$ - and ${ }^{13} \mathrm{C}-\mathrm{NMR}$ for the presence of DIP. Surprisingly, no peaks clearly associated with DIP could be seen in the ${ }^{1} \mathrm{H}$ - and ${ }^{13} \mathrm{C}-\mathrm{NMR}$ spectra under any temperature in $T$. barophilus cell extracts (data not shown). Moreover, DIP, or its derivatives, could not be identified when acquiring

160 specific ${ }^{31} \mathrm{P}-\mathrm{NMR}$ spectra (Figure 2, right panel). In the control experiments performed on $P$. 161 furiosus grown at $100^{\circ} \mathrm{C}$, the specific signal for DIP was clearly visible in both ${ }^{1} \mathrm{H}-$ and ${ }^{13} \mathrm{C}-\mathrm{NMR}$ 162 (data not shown), as well as ${ }^{31} \mathrm{P}-\mathrm{NMR}$ spectra (Figure 2, right panel), which clearly demonstrate that 163 if DIP was indeed produced during growth of T. barophilus, we should be able to detect it in the 164 NMR spectra. To test whether our stress conditions were sufficient to induce DIP accumulation in $T$. barophilus we analyzed samples extracted from cells grown at $98^{\circ} \mathrm{C}$ under high hydrostatic pressure (40 $\mathrm{MPa} / 98^{\circ} \mathrm{C}$, and $70 \mathrm{MPa} / 98^{\circ} \mathrm{C}$ ), since this temperature does not support growth at atmospheric pressure. Even under these conditions we could not detect DIP production in T. barophilus strain MP. Thus far, the absence of DIP synthesis had been observed only in one other Thermococcales species, Palaeococcus ferrophilus, which instead of DIP accumulates increasing amounts of the salt-specific osmolyte, mannosylglycerate (MG), with increasing thermal stress [10]. The lack of

171 DIP synthesis in P. ferrophilus can be attributed to the loss of one of the DIP synthesis genes, e.g. 172 the IPCT/PIPS gene, which is responsible for the conversion of myo-inositol-phosphate, into the 173 DIP precursor di-myo-inositol-di-phosphate (unpublished genome data, available from the JGI, 174 http://genome.jgi.doe.gov). However, the lack of DIP accumulation in T. barophilus cells contrasts 175 with that of $P$. ferrophilus, since the T. barophilus genome harbors a complete set of DIP synthesis genes. 
Cario et al.

To test whether the lack of DIP synthesis could originate from poor expression of the DIP

synthesis genes in T. barophilus, total RNAs were prepared from cells grown under optimal temperature conditions $\left(85^{\circ} \mathrm{C}\right)$ and under thermal stress $\left(90^{\circ}, 95^{\circ} \mathrm{C}\right)$ at two pressure conditions (0.1MPa and 40MPa). Interestingly, we detected the expression of only two of the three DIP synthesis genes in strain MP whichever the temperature considered (Table 2). The mRNA of TERMP_01046, which could encode the inositol-1-monophosphatase (IMP), the last enzyme of the DIP pathway, is the gene expressed at the highest levels, but did not seem to be regulated by temperature. Similarly, the expression of TERMP_01135 which could encode IPS, the first enzyme of the pathway, is slightly up regulated at $90^{\circ} \mathrm{C}$ and $95^{\circ} \mathrm{C}$, although this increase is modest (Table 2). High hydrostatic pressure did not impact the expression levels of these two genes. In contrast the expression of TERMP_01130, which could encode IPCT/PIPS, the second step of the pathway, was not detected (Table 2). These results show that the lack of expression of the IPCT/PIPS gene is responsible for the lack of DIP synthesis in T. barophilus. It is interesting to note that the same gene is responsible for the lack of DIP synthesis in P. ferrophilus, although the overlaying mechanism differs [10]. In the cell, IPS and IMP are responsible for the synthesis of myo-inositol from Dglucose-6-phosphate in two steps via myo-inositol-monophosphate. Myo-inositol and myo-inositolphosphate are central cellular metabolites involved in essential metabolic pathways. Indeed, myoinositol-monophosphate is the constituent of phospholipids and inositol polyphosphates. Myoinositol-monophosphate and CDP:archaeol are the substrate of the archaetidylinositol-1-phosphate synthase to form archaetidylinositol-phosphate, the precursor of archaeal lipids containing a phosphatidylinositol (PI) polar head group [43]. Inositol phospholipids are common in Archaea and ubiquitous in the Thermococcales [44]. All known archaeal genomes present a putative 
Cario et al.

201 in T. barophilus strain MP [45]. To date, there are no known alternative myo-inositol synthesis

202 pathways or homologues of the IPS or IMP genes in the Thermococcales, which may explain why

203 the IPCT/PIPS gene might be the only one dispensable in the DIP synthesis pathway.

3.3 Restoration of DIP synthesis in T. barophilus.

The IPCT/PIPS-IPS synthesis operon structure is highly conserved among Thermococcales with six notable exceptions, T. barophilus, T. gammatolerans, T. paralvinellae, T. nautilus, T. litoralis and T. sibiricus (Table 3) [38]. In the later two strains, the IPCT/PIPS and IPS genes are not linked (Table 3), while in the first three species the two genes are separated by a 4- or 5-gene insertion. This insertion could code for a putative sugar transporter (PST) and be expressed in reverse orientation

211 to the IPCT/PIPS-IPS genes. The same PST is found upstream of the IPS gene in T. litoralis but not

212 in $T$. sibiricus. In the last species, T. nautilus, the two genes are separated by a transposase gene

213 which is in the same orientation as the DIP synthesis genes. In all other species, the intergenic

214 region between IPCT/PIPS and IPS is extremely conserved at the sequence level (Figure 3). To explore whether the 4-gene insertion could be responsible for the lack of DIP synthesis in $T$. barophilus, we engineered its removal and restored an operon-like structure at the IPCT/PIPS - IPS

217 locus in T. barophilus. 63 bases upstream of the IPS ORF that were conserved in the T. litoralis and

218 T. sibiricus genomes were kept in this construct (Figure 3) and fused to the TGA codon of the 219 TERMP_01135 ORF. This 63 pb artificial intergenic region shares extensive similarities with the 220 canonical intergenic sequence observed in other Thermococcus species (Figure 3). Although short, 221 it contains motifs sharing similarity with the promoter sequence of Thermococcales (TATA box) and 222 is properly spaced to function as a promoter to drive the expression of IPS [46, 47]. Two 223 independent deletion mutants, $\mathrm{Tb} \Delta \mathrm{PST} 1$ and $\mathrm{Tb} \Delta \mathrm{PST} 2$, were produced and confirmed by 224 sequencing. As summarized in Table 4, these deletion did not have a significant impact on growth 
Cario et al.

225 parameters of the 2 mutants, at optimal or supra optimal growth temperatures. However, the accumulation of DIP could be observed in the mutants under thermal stress, e.g. at $95^{\circ} \mathrm{C}$, but not under optimal temperature conditions (Figure 3, left panel). Furthermore, transcripts corresponding to the IPCT/PIPS gene were detected in the two mutant derivatives under optimal and thermal stress conditions under atmospheric or high hydrostatic pressure conditions (Table 3). There is no evidence of temperature-dependent gene regulation of the IPCT/PIPS gene, although the production and accumulation of DIP only occurs under thermal stress (Table 2), which supports the occurrence of post transcriptional regulation of the accumulation of osmolytes to respond to stress in $T$. barophilus. These results clearly demonstrate that the lack of DIP synthesis in the piezohyperthermophile $T$. barophilus could be attributed to the presence of the 4-gene PST cluster into the IPCT/PIPS-IPS operon. The mechanism by which this inhibition occurs has not been addressed. These results also strongly suggest that the thermal stress response in T. barophilus has evolved to implicate other mechanisms. Different alternative thermal stress responses in the Thermococcales have been described. Aspartate and glutamate have been shown to accumulate in T. kodakarensis mutants in which the synthesis of DIP had been deleted [49]. In T. barophilus, we found no evidence for the accumulation of these two amino acids under thermal stress. In the wild-type strain MP, apartate and glutamate were estimated to represent 0.07 and 0.14 , and 0.04 and 0.12 $\mu \mathrm{mol} / \mathrm{mg}$ of protein at $85^{\circ} \mathrm{C}$ and $95^{\circ} \mathrm{C}$ respectively. MG has also been shown to substitute to DIP as a thermal stress osmolyte in P. ferrophilus [10]. The potential for this osmolyte to substitute for DIP was later confirmed in the heat adaptation of P. furiosus [48]. In T. barophilus, we notice asimilar significant increase in the accumulation of $\mathrm{MG}$ from $0.1 \mu \mathrm{mol} / \mathrm{mg}$ of protein at $85^{\circ} \mathrm{C}$ to 0.54 $\mu \mathrm{mol} / \mathrm{mg}$ of protein at $95^{\circ} \mathrm{C}$. This observation suggests that in $T$. barophilus the absence of DIP synthesis is compensanted during thermal stress by the accumulation of MG, similarly to what has

248 been observed in the other piezophilic species, P. ferrophilus [10]. 
Cario et al.

3.4 Evolution of DIP synthesis in the piezophilic Thermococcales.

As mentionned above, T. barophilus is the first example of Thermococcales which is

unable to accumulate the osmolyte DIP as a response to thermal stress but possesses a complete set

of DIP synthesis genes. It is only the second species with P. ferrophilus to be unable to accumulate

DIP. Thus far, DIP was shown to accumulate in greater quantities under increased thermal stress in

all strains harboring the DIP synthesis genes. All Thermococcales have been isolated from black

smoker-like hydrothermal fluids or chimney fragments, and exhibit very similar physico-chemical

growth requirements. However, in contrast to the other Thermococcales species knwon to produce

DIP, the T. barophilus and P. ferrophilus species are piezophilic, harboring growth pressure optima

of $40 \mathrm{MPa}$ and $30 \mathrm{MPa}$ respectively [10, 30, 50], which raises questions whether this trait might be

linked to their adaptation to high hydrostatic pressure. In this study we show that the lack of DIP

accumulation of DIP in T. barophilus is linked to the presence of the putative sugar transporter locus

between the IPS and IPCT/PIPS genes. A survey of the proteins involved in the synthesis of DIP

performed on the sequences of the two genes (IPCT/PIPS and IPS) as well as on the putative sugar

transporter genes present upstream of IPS in 6 Thermococcus species clearly shows a congruence between the phylogeny of this locus (Figure S1) and the core genome (Figure 4) and 16S phylogenies [51] with one exception. All topologies demonstrate a well supported group containing 5 of the 6 species harboring the PST locus, comprising T. barophilus, T. litoralis, T. sibiricus, T. sp. strain PK and T. paralvinellae (Figure S1), which supports a common origin of the IPCT/PIPS-PSTIPS cluster in the ancestor of these archaeal species (Figure 4). Horizontal gene transfer might explain the origin of this cluster of genes in the $T$. gammatolerans background. Within the $T$. barophilus cluster, T. litoralis is the only species originating from the surface as well as the only species known to accumulate DIP. In this species, the IPCT/PIPS and IPS genes have become 
273 these results support the existence of a possible link between the adaptation to HHP and the lack of

274 DIP synthesis in the Thermococcales. No matter how tempting this hypothesis, we are still lacking a

275 rationale to explain why the lack of DIP, the canonical thermal stress response molecule would give

276 a growth or selective advantage to piezophilic Thermococcales. Furthermore, the accumulation of

277 DIP in the other species of this cluster or in T. gammatolerans has not yet been investigated, leaving

278 open the possibility that only T. barophilus and P. ferrophilus lack DIP synthesis. Thus, additional

279 experiments on $T$. gammatolerans, which shares the same genetic structure at the IPCT/PIPS-IPS

280 locus as $T$. barophilus, would be required to establish a link between the adaptation to high

281 hydrostatic pressure and thermal stress response.

\section{CONCLUSIONS}

The present study demonstrate that the lack of DIP synthesis and accumulation as a

function of heat stress in T. barophilus is due to the presence of a 4-gene putative sugar transporter

located in reverse orientation between the IPCT/PIPS and IPS genes. Since the second gene of the

putative operon is expressed in the wild type strain, but not the first gene, the rationale for this inhibition is elusive. However, the restoration of the Thermococcus-like two-gene operon restored DIP gene expression and DIP synthesis in T. barophilus. To our knowledge, T. barophilus is only the second example of a Thermococcales which is unable to synthesize DIP as a function of thermal stress, both of which are also adapted to growth under high hydrostatic pressure.

\section{Competing Interests}




\section{Author contributions}

PO, AC, MJ conceived and designed the experiments. MJ, AT created the DIP mutants.

298 AC, AM, PO performed the experiments and analyzed the date. PO, AC, MJ wrote the manuscript.

\section{Acknowledgements}

302 helpful discussions and Matthieu Barba (LBBE, Lyon University) for the core-genome concatenate

303 and phylogenetic tree. This work was supported in part by the Agence Nationale de la Recherche 304 (ANR-10-BLAN-1752-01 Living deep). AC was the recipient of a PhD grant from the Ministère de

305 l'Enseignement Supérieur et de la Recherche. A. T. was supported by a Postdoc fellowships from 306 the Conseil

Général 29 and from Ifremer. 
307

\section{RT-PCR}

\begin{tabular}{llllll}
\hline gene tag & gene & primer & orientation & forward & $\begin{array}{l}\text { gene } \\
\text { position }\end{array}$ \\
\hline TERMP_01046 & IMP & 1046F & Forward & TGGAGTTAGCCCCAGCGGAGA & $96-116$ \\
& & $1046 \mathrm{R}$ & Reverse & AGCACTCGCTGCTATGTCGGT & $615-595$ \\
TERMP_1130 & IPCT/ & $1130 \mathrm{~F}$ & Forward & AGGGCAGTGATTCTTGCGGCT & $13-33$ \\
& PIPS & & & & $924-904$ \\
TERMP_1135 & IPS & $1130 \mathrm{R}$ & Reverse & CGTCTTCATGCTCGCACGTGC & $98-120$ \\
& & 1135F & Forward & TTCCATTGGCAAATGAGCTGCCA & $1084-1063$ \\
16S rRNA & & Arch344F & Forward & ACGGGGYGCAGCAGGCGCGA & \\
& & & & & \\
& & Arch910R & Reverse & GCTCCCCCGCCAATTC &
\end{tabular}

PST deletion verification primers

\begin{tabular}{lllll} 
IPCT/ & PST_up & Forward & TAGCCGGGCAAATAAAAGCTCTCTTT & $1187-1212$ \\
PIPS & & & & \\
\cline { 3 - 5 } IPS & PST_down & Reverse & CCCATAATAGCCGAGATCTCCTC & $74-96$
\end{tabular}

309 Table 1: List of primers used in this study for PCR and RT-PCR.

310

311 
312

\begin{tabular}{ccccc|cc|cc} 
& \multicolumn{3}{c}{ MP } & \multicolumn{2}{c}{ PST1 } & \multicolumn{2}{c}{ PST2 } \\
\cline { 3 - 9 } & & IPS & $\begin{array}{c}\text { IMPCT } \\
\text { /PDIPS }\end{array}$ & IMP & IPS & $\begin{array}{l}\text { IMPCT } \\
\text { /PDIPS }\end{array}$ & IPS & $\begin{array}{r}\text { IMPCT } \\
\text { /PDIPS }\end{array}$ \\
\hline \multirow{4}{*}{$\mathbf{0 . 1} \mathbf{M P a}$} & $90^{\circ} \mathrm{C}$ & 1.38 & nd & 0.9 & 1.31 & 1.14 & 1.13 & 0.90 \\
& $95^{\circ} \mathrm{C}$ & 1.27 & nd & 1.2 & 1.0 & 1.12 & 1.1 & 1.1 \\
\hline \multirow{4}{*}{$\mathbf{4 0 ~ M P a ~}$} & $85^{\circ} \mathrm{C}$ & 0.92 & nd & & 1.20 & 0.78 & & \\
& $90^{\circ} \mathrm{C}$ & 1.21 & nd & & 0.99 & 0.58 & & \\
& $95^{\circ} \mathrm{C}$ & 1.23 & nd & & 1.43 & 0.68 & & \\
\hline
\end{tabular}

314 Table 2: RT-qPCR analysis of DIP synthesis genes in the wild type (MP) and the DIP restored 315 mutants (Tb $\triangle \mathrm{PST} 1, \mathrm{~Tb} \Delta \mathrm{PST} 2)$. Expression levels have been normalized to $16 S \mathrm{rRNA}$ 316 expression level. Expression levels are reported relative to expression levels at $85^{\circ} \mathrm{C}$. Values 317 are averages of duplicate experiments. nd, not detected. 


\begin{tabular}{|c|c|c|c|c|c|c|}
\hline \multirow[b]{2}{*}{ Species } & \multirow[b]{2}{*}{ Strain } & \multicolumn{3}{|c|}{ size (bp) } & \multirow{2}{*}{$\begin{array}{c}\text { neighboring gene(s) } \\
\text { to IPS }^{\mathbf{b}}\end{array}$} & \multirow[t]{2}{*}{ DIP $^{c}$} \\
\hline & & IGS $^{\mathbf{a}}$ & $\begin{array}{l}\text { IPCT/P } \\
\text { IPS }^{\mathbf{a}}\end{array}$ & IPS $^{\mathbf{a}}$ & & \\
\hline T. barophilus & MP & 4938 & 1287 & 1152 & $\begin{array}{l}\text { 4-gene locus } \\
\text { Sugar transporter }\end{array}$ & ND \\
\hline T. paralvinellae & ES1 & 6701 & 1314 & 1152 & $\begin{array}{l}\text { 5-gene locus } \\
\text { Sugar transporter }\end{array}$ & \\
\hline T. nautilus & 30.1 & 1488 & 1305 & 1149 & $\begin{array}{l}1 \text { gene } \\
\text { Transposase }\end{array}$ & \\
\hline T. gammatolerans & $\mathrm{EJ} 3$ & 4778 & 1284 & 1149 & $\begin{array}{l}\text { 4-gene locus } \\
\text { Sugar transporter }\end{array}$ & \\
\hline T. litoralis & $\mathrm{NS}-\mathrm{C}$ & unlinked & 1284 & 1152 & NA & $\begin{array}{c}\text { up to } 0.37 \\
\mu \mathrm{mol} / \mathrm{mg} \text { protein }\end{array}$ \\
\hline T. sibiricus & MM379 & unlinked & 1278 & 1149 & NA & \\
\hline T. kodakarensis & KOD1 & 43 & 1299 & 1149 & IPCT/PIPS & $\begin{array}{c}\text { up to } 0.14 \\
\mu \mathrm{mol} / \mathrm{mg} \text { protein }\end{array}$ \\
\hline T. cleftensis & CL1 & 42 & 1299 & 1149 & IPCT/PIPS & \\
\hline T. sp. & 4557 & 43 & 1299 & 1149 & IPCT/PIPS & \\
\hline T. guaymasensis & TYS & 44 & 1284 & 1149 & IPCT/PIPS & \\
\hline T. onnurineus & NA2 & 61 & 1278 & 1149 & IPCT/PIPS & \\
\hline T. eurythermalis & A501 & 59 & 1284 & 1149 & IPCT/PIPS & \\
\hline T. sp. & AM4 & 44 & 1299 & 1149 & IPCT/PIPS & \\
\hline T. stetteri & K3 & & - & - & NA & $\begin{array}{c}\text { up to } 0.45 \\
\mu \mathrm{mol} / \mathrm{mg} \text { protein }\end{array}$ \\
\hline T. celer & Vu13 & _d & - & - & NA & $\begin{array}{l}\text { up to } 1.2 \mu \mathrm{mol} / \mathrm{mg} \\
\text { protein }\end{array}$ \\
\hline T. zilligii & AN1 & $-d$ & - & - & NA & ND \\
\hline
\end{tabular}

321 Table 3 : Structure of the IPCT/PIPS-IPS locus in the genus Thermococcus. a) size in bp of

322 the IPCT/PIPS and IPS genes and the Intergenic sequence (IGS) between the two genes. b)

323 genomic structure of the IGS sequence; c) quantification of DIP accumulation [5, 49]. d)

324 Genome sequence not known. ND: not detected. NA, not applicable. 
326

$\begin{array}{rccc} & \text { MP } & \text { PST1 } & \text { PST2 } \\ \mathbf{8 5}^{\circ} \mathbf{C} & 0.77 \pm 0.02 & 0.77 \pm 0.02 & 0.78 \pm 0.03 \\ \mathbf{9 0}^{\circ} \mathbf{C} & 0.60 \pm 0.01 & 0.61 \pm 0.02 & 0.62 \pm 0.01 \\ \mathbf{9 5}^{\circ} \mathbf{C} & 0.53 \pm 0.03 & 0.53 \pm 0.08 & 0.53 \pm 0.03 \\ \mathbf{4 0 M P a}-\mathbf{8 5}^{\circ} \mathbf{C} & 1.24 \pm 0.03 & 1.24 \pm 0.02 & 1.25 \pm 0.04\end{array}$

328 Table 4: Growth rate for the wild type (MP) and the two DIP mutant clones (Tb $\Delta$ PST1, $329 \mathrm{~Tb} \Delta \mathrm{PST} 2$ ) of strain MP. The values are average from four independent experiments.

330

331 


\section{Figure captions}

Figure 1: DIP synthesis pathway (A) and genetic organization (B) in Thermococcus

334 barophilus strain MP.

Figure 2: Extracts from ${ }^{31} \mathrm{P}$ NMR spectra of partially purified osmolytes from the

wild type (MP) and one of the DIP restoration mutant of $T$. barophilus (Tb $\Delta \mathrm{PST} 2$ ) grown

338 under optimal temperature $\left(85^{\circ} \mathrm{C}\right)$ or under heat stress $\left(95^{\circ} \mathrm{C}\right)$ at atmospheric pressure.

339 Osmolytes purified from Pyrococcus furiosus grown at $100^{\circ} \mathrm{C}$ ( $\left.\mathrm{Pf} 100\right)$ were used as a

340 positive control to assign the specific peak for DIP (-1.1 ppm).

Figure 3: Detailed alignment of the sequence upstream of the IPS start codon in the

343 Thermococcus genus.

Figure 4: Genetic organization of the DIP synthesis loci in the Thermococcales. The phylogenetic tree of the Thermococcales has been calculated on the concatenate protein sequence of the strict core genome (544 families) with PhyML on 1000 bootsptrap replicates.

Figure S1: Phylogenetic trees of the IPCT/PIPS, IPS and putative sugar transporter

350 in the Thermococcales. All genes have been aligned with MUSCLE. Alignements were 351 optimized by hand before the calculation of phylogenetic trees with PhyML on 1000 bootsrap 352 replicates. Trees have been rooted with the IPCT/PIPS, IPS and PST loci of P. horikoshii. 


\section{Literature}

356 1. Prieur, D., Microbiology of deep-sea hydrothermal vents. Trends in Biotechnology, 1997. 15(7): p. 242-244.

358 2. Brown, A.D., Microbial water stress. Bacteriological Reviews, 1976. 40(4): p. 803846.

$3603 . \quad$ Galinski, E.A., Osmoadaptation in bacteria. Advances in microbial physiology, 1995.

361

362

363

364 37: p. 272-328.

4. Ventosa, A., J.J. Nieto, and A. Oren, Biology of moderately halophilic aerobic bacteria. Microbiology and Molecular Biology Reviews, 1998. 62(2): p. 504-+.

5. Lamosa, P., et al., Effects of temperature, salinity, and medium composition on compatible solute accumulation by Thermococcus spp. Applied and Environmental Microbiology, 1998. 64(10): p. 3591-3598.

6. Martins, L.O. and H. Santos, Accumulation of mannosylglycerate and di-myo-inosytolphosphate by Pyrococcus furiosus in response to salinity and temperature. Applied and Environmental Microbiology, 1995. 61(9): p. 3299-3303.

7. Vannier, P., et al., Complete genome sequence of the hyperthermophilic piezophilic, heterotrophic and carboxydotrophic archaeon Thermococcus barophilus MP. Journal of Bacteriology, 2011. 193: p. 1481-1482.

8. Holden, J.F. and J.A. Baross, Enhanced thermotolerance and temperature-induced changes in protein-composition in the hyperthermophilic archaeon ES4. Journal of Bacteriology, 1993. 175(10): p. 2839-2843.

9. Marteinsson, V.T., et al., Physiological responses to stress conditions and barophilic behavior of the hyperthermophilic vent archaeon Pyrococcus abyssi. Applied and Environmental Microbiology, 1997. 63(4): p. 1230-1236.

10. Neves, C., M.S. da Costa, and H. Santos, Compatible solutes of the hyperthermophile Palaeococcus ferrophilus: Osmoadaptation and thermoadaptation in the order Thermococcales. Applied and Environmental Microbiology, 2005. 71(12): p. 80918098.

11. Ooi, T., Thermodynamics of protein-folding - effects of hydration and electrostatic interactions. Advances in Biophysics, Vol 30, 1994, 1994. 30: p. 105-154.

12. Nunes, O.C., et al., Compatible solutes in the thermophilic bacteria Rhodothermus marinus and Thermus thermophilus. Applied and Environmental Microbiology, 1995. 61(6): p. 2351-2357.

13. Scholz, S., et al., Di-myo-inositol-1,1'-phosphate - a new inositol phosphate isolated from Pyrococcus woesei. FEBS Letters, 1992. 306(2-3): p. 239-242.

14. Martins, L.O., et al., New compatible solutes related to di-myo-inositol-phosphate in members of the order Thermotogales. Journal of Bacteriology, 1996. 178(19): p. 56445651 .

15. da Costa, M.S., H. Santos, and E.A. Galinski, An overview of the role and diversity of compatible solutes in Bacteria and Archaea. Advances in biochemical engineering/biotechnology, 1998. 61: p. 117-53.

16. Santos, H. and M.S. da Costa, Organic solutes from thermophiles and hyperthermophiles. Hyperthermophilic Enzymes, Pt C, 2001. 334: p. 302-315.

17. Empadinhas, N., et al., Pathway for the synthesis of mannosylglycerate in the hyperthermophilic archaeon Pyrococcus horikoshii - Biochemical and genetic characterization of key enzymes. Journal of Biological Chemistry, 2001. 276(47): p. 43580-43588.

18. Silva, Z., et al., Combined effect of the growth temperature and salinity of the medium 
on the accumulation of compatible solutes by Rhodothermus marinus and Rhodothermus obamensis. Extremophiles, 1999. 3(2): p. 163-172.

19. Lamosa, P., et al., Protein stabilization by compatible solutes - Effect of diglycerol phosphate on the dynamics of Desulfovibrio gigas rubredoxin studied by NMR. European Journal of Biochemistry, 2003. 270(23): p. 4606-4614.

20. Yancey, P.H., Organic osmolytes as compatible, metabolic and counteracting cytoprotectants in high osmolarity and other stresses. Journal of Experimental Biology, 2005. 208(15): p. 2819-2830.

21. Borges, N., et al., Comparative study of the thermostabilizing properties of mannosylglycerate and other compatible solutes on model enzymes. Extremophiles, 2002. 6(3): p. 209-216.

22. Pais, T.M., et al., Relationship between protein stabilization and protein rigidification induced by mannosylglycerate. Journal of Molecular Biology, 2009. 394(2): p. 237250.

23. Yayanos, A.A., Microbiology to 10,500 metters in the deep-sea. Annual Review of Microbiology, 1995. 49: p. 777-805.

24. Zobell, C.E., Bacterial life at the bottom of the Philippine trench. Science, 1952. 115(2993): p. 507-508.

25. Michels, P.C. and D.S. Clark, Pressure-dependence of enzyme catalysis, in Biocatalysis at Extreme Temperatures, M.W.W. Adams and R.M. Kelly, Editors. 1992, American Chemical Society: Washington, DC. p. 108-121.

26. Oger, P. and M. Jebbar, The many ways of coping with pressure. Research in Microbiology, 2010. 161: p. 799-809.

27. Le Chatelier, H.L., Sur un énoncé général des lois d'équilibres chimiques. Comptesrendus de l'Académie des sciences, 1884. 99: p. 786-789.

28. Eisenmenger, M.J. and J.I. Reyes de Corcuera, High pressure enhancement of enzymes: A review. Enzyme and Microbial Technology, 2009. 45(5): p. 331-347.

29. Jannasch, H.W. and M.J. Mottl, Geomicrobiology of deep-sea hydrothermal vents. Science, 1985. 229(4715): p. 717-725.

30. Marteinsson, V.T., et al., Thermococcus barophilus sp. nov., a new barophilic and hyperthermophilic archaeon isolated under high hydrostatic pressure from a deep-sea hydrothermal vent. International Journal of Systematic Bacteriology, 1999. 49: p. 351359.

31. Zeng, S., et al., Pyrococcus $\mathrm{CH1}$, an obligate piezophilic hyperthermophile : extending the upper pressure-temperature limits for life. ISME Journal, 2009. 3(7): p. 873-876.

32. Kasahara, R., et al., Piezo-adapted 3-isopropylmalate dehydrogenase of the obligate piezophile Shewanella benthica DB21MT-2 isolated from the 11,000-m depth of the Mariana trench. Bioscience Biotechnology and Biochemistry, 2009. 73(11): p. 25412543.

33. Morita, T., Structure-based analysis of high pressure adaptation of alpha-actin. Journal of Biological Chemistry, 2003. 278(30): p. 28060-28066.

34. Nishiguchi, Y., T. Miwa, and F. Abe, Pressure-adaptive differences in lactate dehydrogenases of three hagfishes: Eptatretus burgeri, Paramyxine atami and Eptatretus okinoseanus. Extremophiles, 2008. 12(3): p. 477-480.

35. Chilukuri, L.N., D.H. Bartlett, and P.A.G. Fortes, Comparison of high pressureinduced dissociation of single-stranded DNA. binding protein (SSB) from high pressure-sensitive and high pressure-adapted marine Shewanella species. Extremophiles, 2002. 6(5): p. 377-383. 
36. Rodionov, D.A., et al., Genomic identification and in vitro reconstitution of a complete biosynthetic pathway for the osmolyte di-myo-inositol-phosphate. Proceedings of the National Academy of Sciences of the United States of America, 2007. 104(11): p. 4279-4284.

37. Rodrigues, M.V., et al., A unique beta-1,2-mannosyltransferase of Thermotoga maritima that uses di-myo-inositol phosphate as the mannosyl acceptor. Journal of Bacteriology, 2009. 191(19): p. 6105-6115.

38. Goncalves, L.G., et al., Evolution of the biosynthesis of di-myo-inositol phosphate, a marker of adaptation to hot marine environments. Environmental Microbiology, 2012. 14(3): p. 691-701.

39. Thiel, A., et al., Genetic Manipulations of the Hyperthermophilic Piezophilic Archaeon Thermococcus barophilus. Applied and Environmental Microbiology, 2014. 80(7): p. 2299-2306.

40. Chomczynski, P. and N. Sacchi, The single-step method of RNA isolation by acid guanidinium thiocyanate-phenol-chloroform extraction: twenty-something years on. Nature Protocols, 2006. 1(2): p. 581-585.

41. Voorhorst, W.G.B., et al., Characterization of the celB gene coding for betaglucosidase from the hyperthermophilic archaeon Pyrococcus furiosus and its expression and site-directed mutation in Escherichia coli. Journal of Bacteriology, 1995. 177(24): p. 7105-7111.

42. Reed, R.H., et al., Carbohydrate accumulation and osmotic-stress in cyanobacteria. Journal of General Microbiology, 1984. 130(JAN): p. 1-4.

43. Morii, H., et al., Ubiquitous distribution of phosphatidylinositol phosphate synthase and archaetidylinositol phosphate synthase in Bacteria and Archaea, which contain inositol phospholipid. Biochemical and Biophysical Research Communications, 2014. 443(1): p. 86-90.

44. Oger, P. and A. Cario, Adaptation of the archaeal membrane. Biophysical Chemistry, 2013. 15: p. 42-56.

45. Vannier, P., et al., Complete Genome Sequence of the Hyperthermophilic, Piezophilic, Heterotrophic, and Carboxydotrophic Archaeon Thermococcus barophilus MP. Journal of Bacteriology, 2011. 193(6): p. 1481-1482.

46. Thomm, M. and G. Wich, An archaebacterial promoter element for stable RNA genes with homology to the TATA box of higher eukaryotes. Nucleic Acids Research, 1988. 16(1): p. 151-163.

47. Reiter, W.D., U. Hudepohl, and W. Zillig, Mutational analysis of an archaebacterial promoter - Essential role of a TATA box for transcription efficiency and start-site selection in vitro. Proceedings of the National Academy of Sciences of the United States of America, 1990. 87(24): p. 9509-9513.

48. Esteves, A.M., et al., Mannosylglycerate and Di-myo-Inositol Phosphate Have Interchangeable Roles during Adaptation of Pyrococcus furiosus to Heat Stress. Applied and Environmental Microbiology, 2014. 80(14): p. 4226-4233.

49. Borges, N., et al., Thermococcus kodakarensis mutants deficient in di-myo-inositol phosphate use aspartate to cope with heat stress. Journal of Bacteriology, 2010. 192(1): p. 191-197.

50. Takai, K., et al., Palaeococcus ferrophilus gen. nov., sp nov., a barophilic, hyperthermophilic archaeon from a deep-sea hydrothermal vent chimney. International Journal of Systematic and Evolutionary Microbiology, 2000. 50: p. 489-500.

51. Hensley, S., et al., Thermococcus paralvinellae sp. nov. and Thermococcus cleftensis sp. nov. of hyperthermophilic heterotrophs from deep-sea hydrothermal vents. 
International Journal of Systematic and Evolutionary Microbiology, 2014. 64(11): p. 3655-3659. 
A

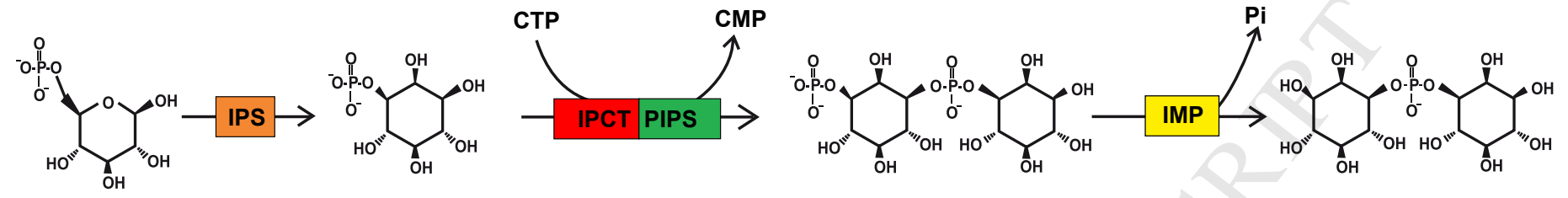

Glucose-6-phosphate L-myo-inositol-1-phosphate (G6P)

(I1P)

Phospho-di--myo-inositol-1-phosphate (PDIP) (DIP)

B

T. barophilus

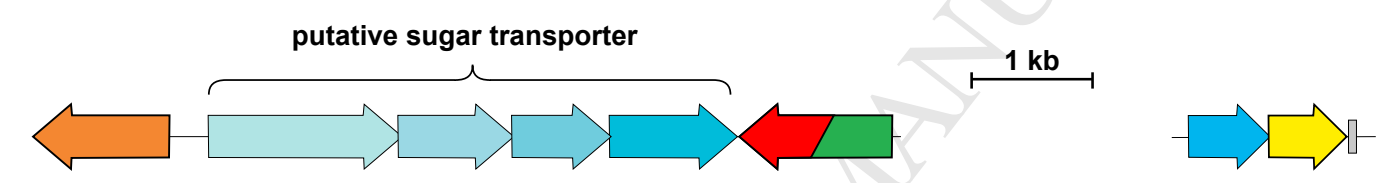

Cario et al. Restoration of DIP synthesis in T. barophilus

Figure 1 


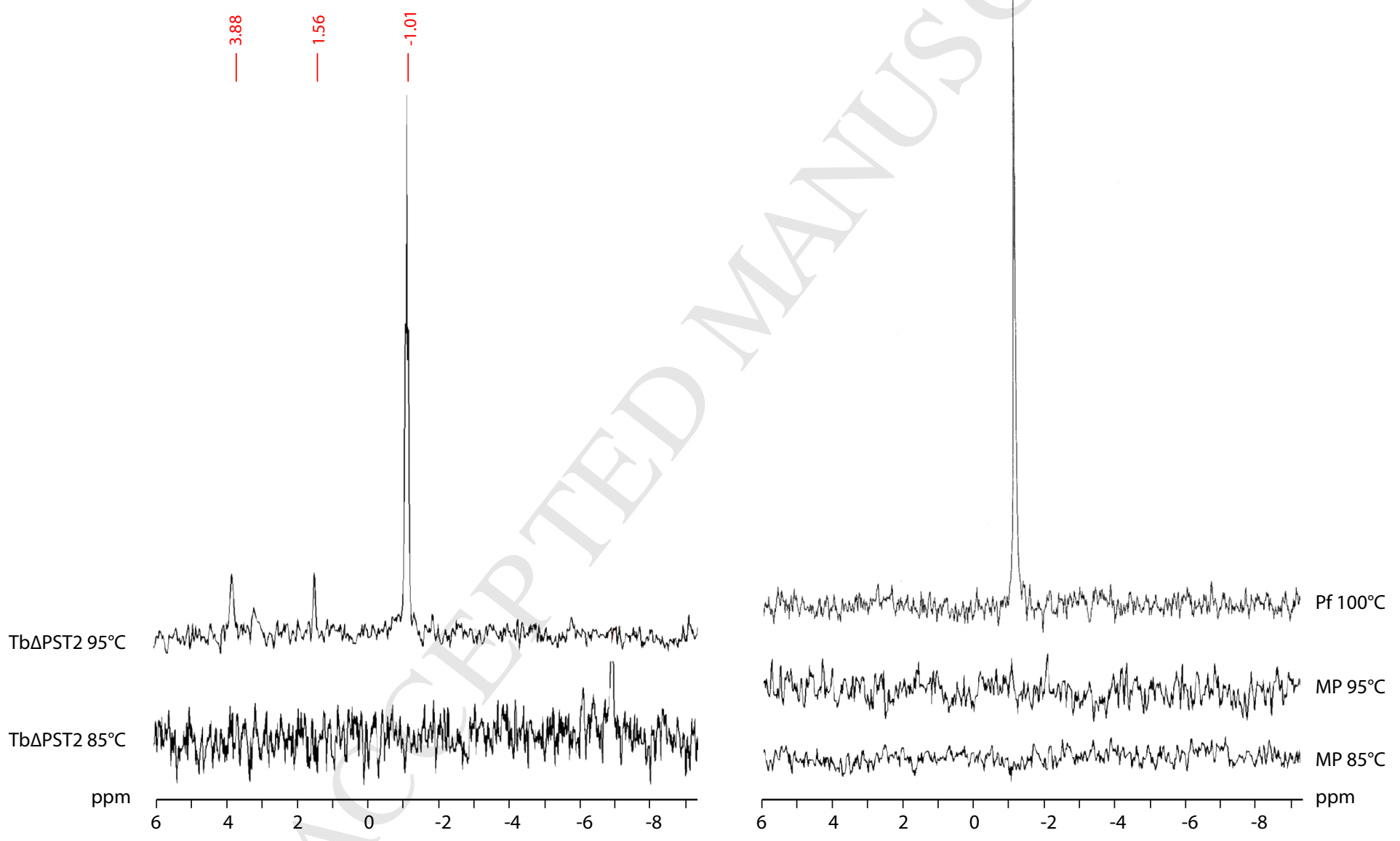

Cario et al. Restoration of DIP synthesis in T. barophilus

Figure 2 


\author{
T. barophilus MP \\ T. litoralis NS-C \\ T. sibiricus MM379 \\ T. paralvilellae ESI \\ T. kodakarensis KOD1 \\ T. cleftensis CL1 \\ T. sp. 4557 \\ T. guaymasensis TYS \\ T. onnurineus NA2 \\ T. eurytehrmalis A501 \\ T. sp. AM4 \\ T. nautilii 30.1 \\ T. gammatolerans EJ3
}

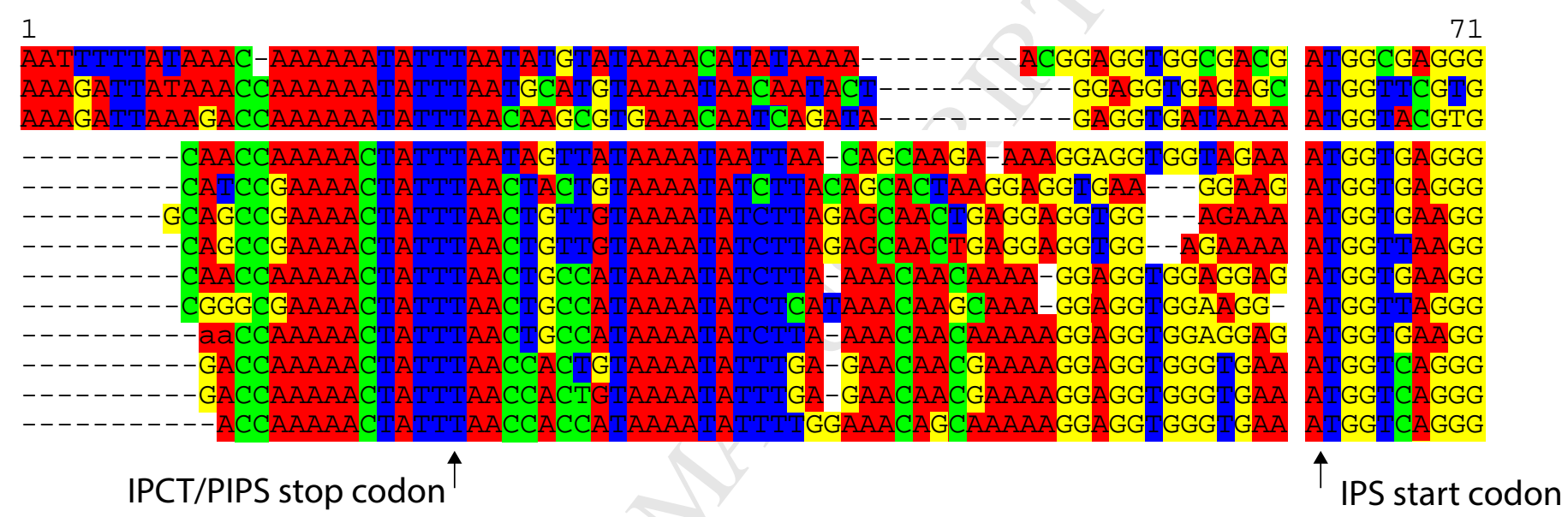

Cario et al. Restoration of DIP synthesis in T. barophilus

Figure 3 


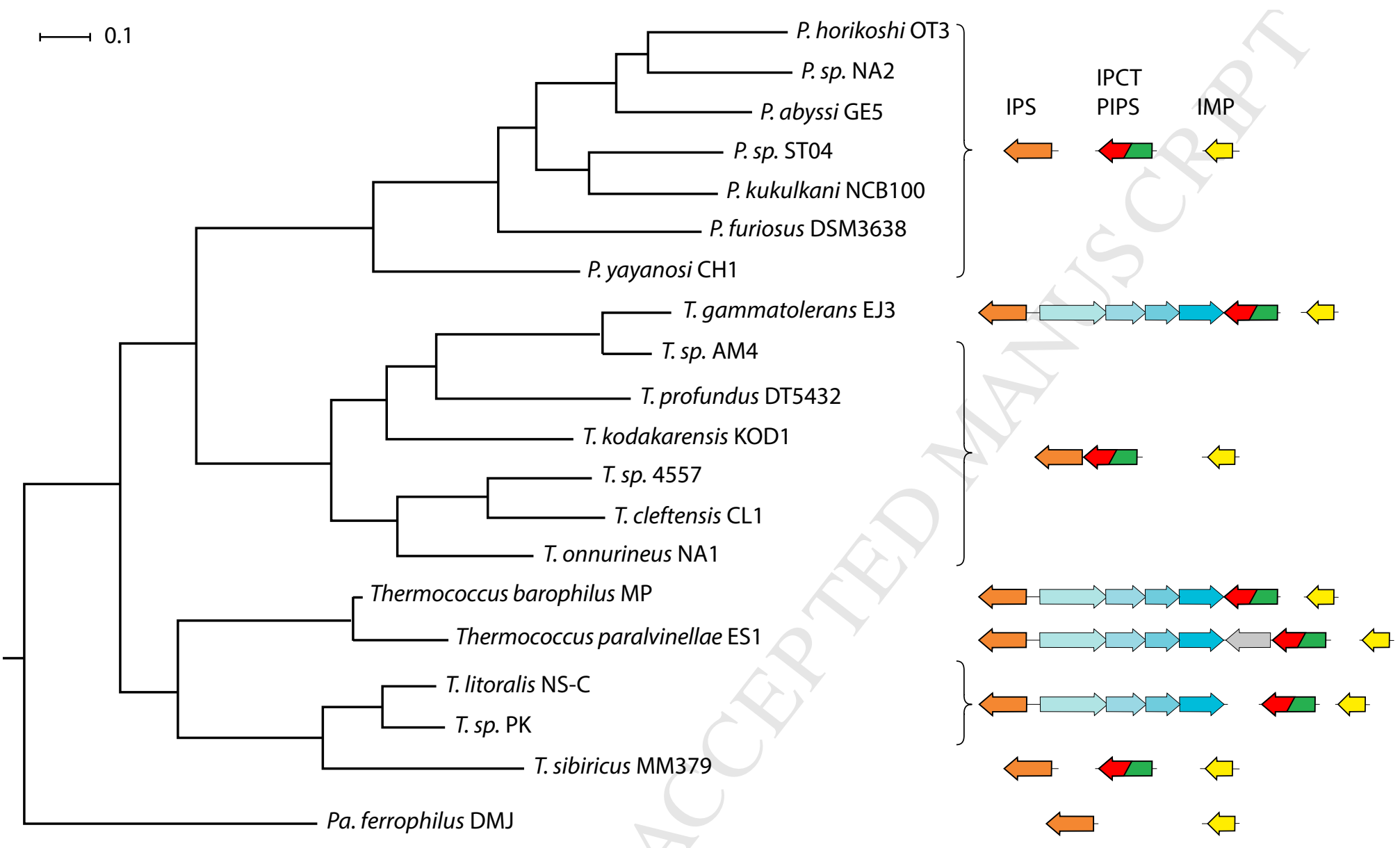

Cario et al. Restoration of DIP synthesis in T. barophilus

Figure 4 

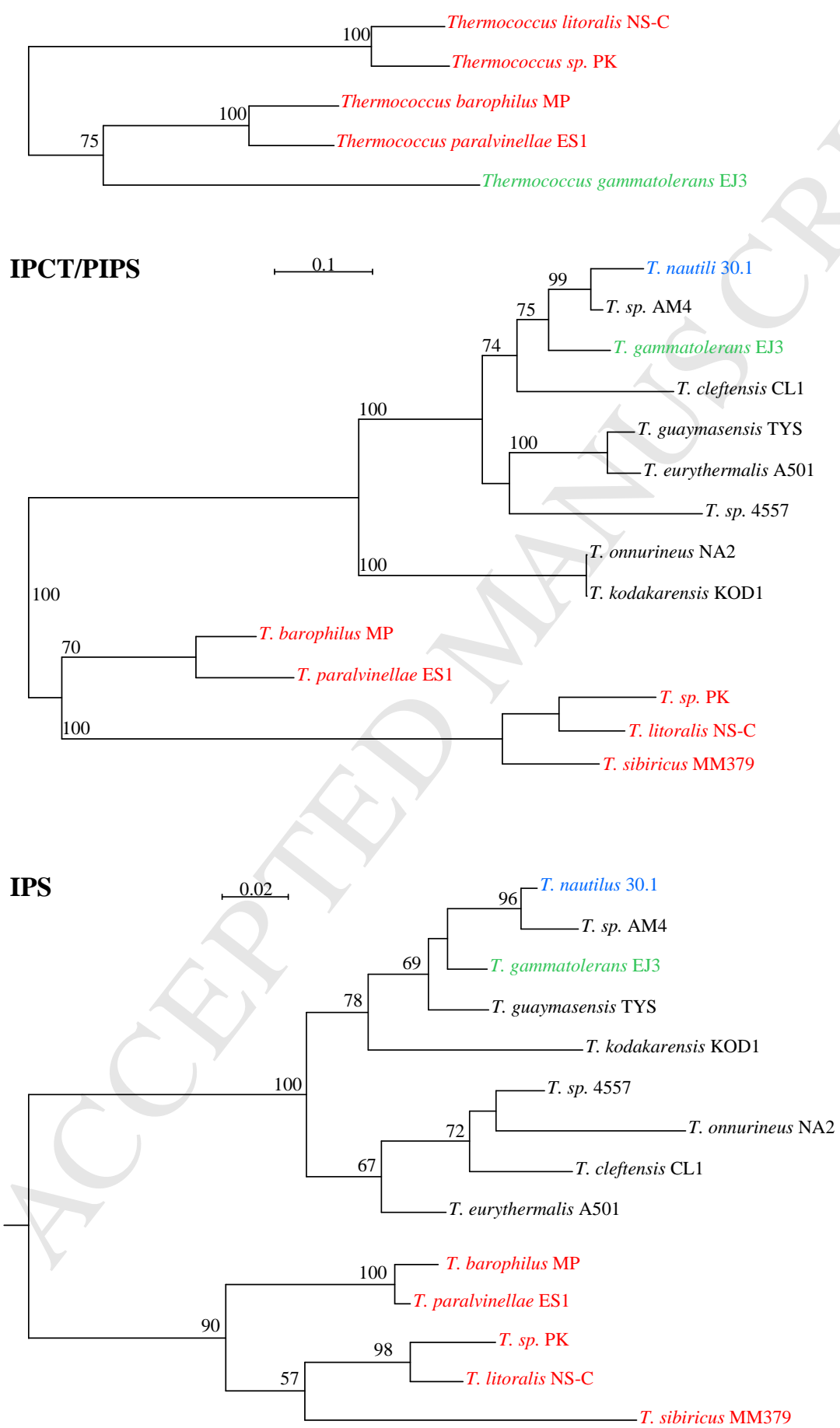

Cario et al. Restoration of DIP synthesis in T. barophilus Figure S1 